Old Dominion University

ODU Digital Commons

World Languages and Cultures Faculty

Publications

World Languages \& Cultures

2019

The Family of Japanese no-wa Cleft Construction: A Registerbased Analysis

Michiko Kaneyasu

Old Dominion University, mkaneyas@odu.edu

Follow this and additional works at: https://digitalcommons.odu.edu/worldlanguages_pubs

Part of the Discourse and Text Linguistics Commons, Japanese Studies Commons, and the Other

Linguistics Commons

Original Publication Citation

Kaneyasu, M. (2019). The family of Japanese no-wa cleft construction: A register-based analysis. Lingua, 217, 1-23. https://doi.org/10.1016/j.lingua.2018.10.002

This Article is brought to you for free and open access by the World Languages \& Cultures at ODU Digital Commons. It has been accepted for inclusion in World Languages and Cultures Faculty Publications by an authorized administrator of ODU Digital Commons. For more information, please contact digitalcommons@odu.edu. 
Author: Michiko Kaneyasu. This is the author final version.

Published in Lingua: https://doi.org/10.1016/..lingua.2018.10.002

\title{
The family of Japanese no-wa cleft construction: A register-based analysis
}

\author{
Michiko Kaneyasu
}

Old Dominion University

\begin{abstract}
:
This paper presents a comparative study of the Japanese (pseudo-)cleft no-wa construction, schematized as: [clause] no-wa [NP/AdvP/clause] (da), in four spoken/written registers: informal conversations, academic presentations, news reports, and newspaper editorials. The study finds that the no-wa cleft appears more frequently in non-objective discourse that deals with a higher level of complexity. Close examination of instantiations of the no-wa cleft uncovers various register-oriented functions that show a varied degree of family resemblance with one another. These functions can be subsumed under two general functional properties of the no-wa construction: highlighting function at the local level and (retrospective) anticipatory function at the global level. This study shows that the family resemblance model provides a realistic and inclusive (albeit complex) account of the relationship between grammatical forms, their functions, and the contexts of use.
\end{abstract}

\section{Keywords:}

register; genre; Japanese pseudo-cleft; no-wa cleft; family resemblance

\section{Introduction}

The interrelationship between grammar and context of use is an essential point of inquiry in usage-based linguistics and other related studies that aim to understand real language use. There are various levels and types of context, from turn-based sequential interaction to written versus spoken mediums. Regardless of the level or type, the basic premise is that linguistic forms, functions, and the knowledge of form-function pairs, are inseparable from the interactional, textual, institutional, and social contexts in which they are at work (e.g. Bybee, 2006; Chafe, 1994; Du Bois, 1987; Fillmore, 1982; Hopper, 1998; Schegloff, 1996; Schiffrin, 1987; Tomasello, 2003). The type of context that concerns the present study is that of register or genre. Register ${ }^{1}$ is broadly defined as the use of language in a social situation for a specific purpose (Ferguson, 1994). This concept is often contrasted with dialects, defined as language varieties based on geographical or social group to which speakers belong (e.g. Bruthiaux, 1994; see also Biber and Conrad, 2009: 11-15). Examples of register include sports announcer talk (e.g. Ferguson, 1983), academic lectures (e.g. Thompson, 2003), cooking recipes (e.g. Fischer, 2013), and news reports (e.g. Bednarek, 2006), among many others.

Register studies generally identify situational characteristics as well as recurring lexical and syntactic features that characterize one or more registers (e.g. Biber, 2006; Ferguson, 1983), or investigate how the same or similar functions are carried out by different linguistic (and nonlinguistic) features in related registers (e.g. Bednarek, 2006; Fischer, 2013). Although it is not part of mainstream register studies, to the extent that 'several different situational characteristics

\footnotetext{
${ }^{1}$ For convenience, the term 'register' will be used instead of 'registers or genres' in this paper. Some studies distinguish register and genre (see Biber, 1994; Biber and Conrad, 2009).
} 
can be associated with a single linguistic characteristic' (Biber and Conrad, 2009: 69), investigating a single grammatical construction in multiple registers can further our understanding of the interrelationship between form, function, and situations of use. For example, Matsumoto (2015) found that what she calls the stand-alone noun-modifying construction was used in a wide range of registers, including stage directions, blogs, and infomercials, whose situational characteristics were compatible with the invocatory function of the construction. The present study aims to add to this line of inquiry by investigating the use of the no-wa cleft construction in four diverse well-defined registers.

As described in Sections 3 and 4, the construction, schematized as [clause] no-wa [NP/AdvP/clause] (da), appear in all four registers. In spoken registers, we find many instances of the construction that seem partial or disjointed. While these fragment-looking tokens are shown to have a specific discourse function (Mori 2014, see Section 2), a comparative analysis of this and other types of the no-wa cleft construction, found in different registers, reveals that they are all related by partially overlapping and intersecting features. That is, just like individual members of a family partially share some physical and personality (and behavioral) traits among themselves, tokens of the no-wa cleft construction share similar but not identical formal and functional features. Important points are that no single feature is found in all members of a family and that overlapping features resemble but do not exactly match each other. The family resemblance model (Wittgenstein, 1953; see also Hopper, 2001; Bybee and Eddington, 2006) provides a realistic and inclusive (albeit complex) account of the relationship between grammatical forms, their functions, and the contexts of use.

The organization of the paper is as follows. Section 2 provides a brief overview of the traditional and existing approaches to no-wa cleft construction and situates the current study within the previous scholarship on this grammatical form. Section 3 presents the data set and method used in this study. The results of quantitative and qualitative analyses are presented and discussed from a comparative perspective in Section 4. Section 5 discusses the family resemblance relations among the identified functions, and Section 6 concludes the paper with a brief discussion on different levels of context.

\section{Previous approaches to cleft construction}

The no-wa cleft construction is one type of topic-comment copular sentence structure, represented as [clause] no-wa [NP/AdvP/clause] (da). In this structure, a clause, nominalized by the nominalizer no, is followed by the topic particle wa, and the comment, which can be a nominal/adverbial word/phrase or a (nominalized) clause, is followed by an optional copula da or its variants. ${ }^{2}$ Previous sentence-level analyses of this structure have described it as a complex focus sentence structure derived from an underlying simplex sentence (e.g. Martin, 1975). The information in the simplex sentence is split into two parts in the derived complex sentence, with the presupposition in the topic position and the focus in the comment position. In the following source-cleft pair, for example, kono hon 'this book' in (1a) is considered extracted and placed in the comment position in (1b).

(a)

Source sentence

鈴木さんがこの本を読んでいる。

suzuki san ga kono hon o yonde-iru.

(name) Ms./Mr. NOM this book ACC read-ASP

'Ms. Suzuki is reading this book.'

(b) Cleft sentence

\footnotetext{
2 The use or non-use of the copula da or its variants most likely has some effect on the function of the construction. However, this issue is beyond the scope of the present study.
} 
鈴木さんが読んでいるのはこの本(を)だ。

suzuki san ga yonde-iru no wa kono hon (o) da.

(name) Ms./Mr. NOM read-ASP NML TOP this book ACC COP

'What Ms. Suzuki is reading is this book. / It is this book that Ms. Suzuki is reading.'

Structurally, (1b) is similar to the English pseudo-cleft or wh-cleft, as in the first translation; the topical/subject clause expresses the presupposition and the pre-copula NP expresses the focus (Inoue, 1982). At the same time, (1b) also shares a similarity with the English it-cleft sentence, as in the second translation, in that the clause is embedded as the topic/subject of the sentence by the nominalizer no or complementizer 'that,' respectively. As Prince (1978) demonstrates, the two types of clefts in English have different discourse functions. For Japanese examples in this paper, both wh-cleft and it-cleft English translations are provided whenever possible; when no wh-cleft is available or one type seems to better represent the contextual meaning of the no-wa cleft, I use only one of the forms (or the closest possible form) in the translation. ${ }^{3}$

Previous studies on the no-wa cleft sentence have discussed issues such as whether no is a nominalizer or an indefinite pronoun (e.g. Nakau, 1973), conditions for particle retention or deletion (Haig, 1981), and types of syntactic operation involved in deriving the no-wa cleft (e.g. Hoji, 1990). Beyond sentential level, the no-wa cleft has also been investigated from the perspectives of 'discourse topic' (Sunakawa, 1995, 2005, 2007), 'territory of information' (Kamio, 1991), and 'discourse frame' (Mori, 2014). The discourse-based studies offer some insights into the functional motivations for the use of this construction within given contexts.

Sunakawa $(1995,2005,2007)$ presents comparative analyses of no-wa and no-ga cleft sentences from the perspective of discourse topic. Her data is a collection of published essays, magazine articles, novels, and textbooks. Her studies demonstrate three functions of the no-wa cleft. First, the most common function is to introduce a discourse topic. Predictable information is presented in the topic position, while unpredictable information, which becomes a discourse topic in the subsequent discourse, is introduced in the comment position. In the next example, chichi 'father' is the unpredictable information introduced with the no-wa cleft, and it continues to be discussed in the following context.

$$
\text { 私とアメリカを結びつけたのは、父である。 }
$$

watashi to amerika o musubitsuke-ta no wa chichi dearu. I and America ACC connect-PST NML TOP father COP

'It is my father who tied me and the U.S. / What tied me and the U.S. is my father.' (Sunakawa, 2007:31; all translations of her examples by the author)

The second function of the no-wa cleft is to present a situational framework for the main topic of the subsequent discourse. Unlike the previous example, unpredictable information is presented in the topic position and temporal information is given in the comment position. This type of cleft tends to appear at the beginning of essays and articles.

$$
\text { 安部修二さん(43)が「牛井の吉野家」でアルバイトをはじめたのは昭和 } 46 \text { 年だった。 }
$$

abe shuji san (43) ga 'gyuudon no yoshinoya' de arubaito o hajime-ta no wa

\footnotetext{
${ }^{3}$ The (in)compatibility between the two types of English clefts and Japanese one is an interesting topic, but it would take too much space to discuss this issue in this paper.
} 
(name) Mr. (age) NOM beef.bowl GEN (name) LOC part.time.job ACC begin-PST NML TOP shoowa 46-nen dat-ta.

Showa 46-year COP-PST

'It was in 1971 that Mr. Shuji Abe (43) began to work part time at "Yoshinoya."' (Sunakawa, 2005:121)

The third function is to bring the ongoing discourse topic to a close. In this case, both the topic and predicate positions contain predictable information. In the following example, the use of the demonstrative pronoun sono points to the information in the preceding context. This creates a situation where information flow is stalled, which helps to indicate a topic shift. This type of no-wa cleft tends to appear at the end of paragraphs.

お寺や古い民家での昼寝が気持ちよいのは、そのせいなのです。

otera ya furui minka de no hirune ga kimochiyoi no wa, sono sei-na no desu. temple and old house LOC GEN nap NOM feel.good NML TOP that reason-ATT SE COP

'It is because of these (reasons) that taking a nap in a temple or an old house feels good.'

(Sunakawa, 2007:124)

The no-wa cleft may also contain elements other than nouns and noun phrases in the comment position. Sunakawa explains that this is because the basic function of the sentence pattern $\mathrm{A}(\mathrm{no})$ wa $\mathrm{B}$ da is simply to present a missing piece of information to fill in the gap in the given presupposition. In the following example, it is presupposed that something appeared, and ip-piki no kuma 'one bear' functions to identify that something.

$$
\text { その時現れたのは一匹のクマだった。 }
$$

sono toki araware-ta no wa ip-piki no kuma dat-ta.

that time appear-PST NML TOP one-CLS GEN bear COP-PST

'It was a bear that appeared then. / What appeared then was a bear.'

(Sunakawa, 2007:27)

Missing information (or the answer to an implied question) can be of various types, from a noun referring to an animate or inanimate object, to an adverb hajimete 'for the first time,' to a clause referring to a reason, as in the following example.

$$
\text { 人里にクマが現れたのは、森に食糧が不足しているためだ。 }
$$

hitozato ni kuma ga araware-ta no wa, mori ni shokuryoo ga fusokushite-iru tame da. village DAT bear NOM appear-PST NML TOP forest DAT food NOM lack-ASP because COP

'It is because there is a shortage of food that a bear appeared in the village.'

(Sunakawa, 2007:22)

The three discourse-based functions found in Sunakawa's studies may be specific to the type of written registers, that is, essays, magazine articles, and novels, examined in her study. In fact, 
even in isolation, the no-wa clefts (2)-(6) seem to evoke certain types of writing/texts in the minds of their readers. Only empirical studies of other registers can reveal the generalizability of these functions.

Kamio (1991) applies his theory of territory of information (e.g. Kamio, 1979) to the Japanese (and English) cleft constructions. Territory of information is defined by the pragmatic notion of 'closeness' between a given piece of information and the speaker (writer) or the hearer (reader). If the information expresses facts, experiences, or stories about the speaker or someone close to the speaker, the information falls into the speaker's territory. The information within the speaker's territory is expressed in the direct form, while the information that falls outside the speaker's territory is expressed in indirect form, which includes a hedge or a rhetorical question. Kamio (1991) claims that the presuppositional part (P-part) of the Japanese cleft always takes the direct form, which indicates that the P-part of this cleft only accepts information falling into the speaker's (writer's) territory of information.

(7a) is an example of a no-wa cleft with its P-part expressing information within the speaker's territory. However, such information can also be expressed using non-cleft declarative sentences, as in (7b). According to Kamio, both types of sentences imply the speaker's recognition that the information is true, but only the non-cleft declarative sentence also implies the speaker's involvement with propositional content, for example, the speaker directly experiencing or observing the action or situation being described. Kamio's point, which is similar to what Prince (1978) claims about English it-clefts, is that the speaker uses cleft sentences to present information in the P-part as factual and indisputable, without implying the speaker's accountability or responsibility.

$$
\text { 大家洪介が三条河原町の旅館へ戻ってきたのは } 5 \text { 時だった。 }
$$

ooya koosuke ga sanjoo-kawaramachi no ryokan e modotteki-ta no wa 5-ji dat-ta. (name) NOM (name) GEN inn to return-PST NML TOP 5-o'clock COP-PST

'It was 5 o'clock when Oya Kosuke returned to the inn in Sanjo-Kawaramachi.' (Kamio, 1991: 358 and 368; from Inoue, 1979: 36)

$$
\text { 大家洪介は } 5 \text { 時に三条河原町の旅館へ戻ってきた。 }
$$

ooya koosuke wa 5-ji ni sanjoo-kawaramachi no ryokan e modotteki-ta. (name) TOP 5-o'clock DAT (name) GEN inn to return-PST

'Oya Kosuke returned to the inn in Sanjo-Kawaramachi at 5 o'clock.' (Kamio, 1991; modified by the author)

Examples in Kamio (1991) come from novels or essays. In these registers (as well as in other registers such as academic presentations and newspaper articles), all information presumably falls under the writer's territory of information. Furthermore, factual and indisputable interpretations can be seen in the non-cleft A no-wa B structure, such as (8) below from the newspaper editorial data used in the present study. This is a non-cleft sentence in which the nowa clause functions as the subject of the evaluative predicate. Even in this non-cleft example, the information in the topic clause (i.e. 'the abduction issue is not showing progress') is given factual interpretation. This suggests that the indisputable reading is not an exclusive property of the no-wa cleft. Thus, although Kamio's claim that only direct forms generally appear within nowa cleft topic clause is confirmed in the present data as well, the theory of territory of 
information and the presentation of information as (if it is) a fact do not fully explain why speakers and writers choose to use cleft constructions over non-cleft declarative sentences.

(8)＼cjkstart拉致問題が進展しないのは心が痛む。

rachi mondai ga shintenshi-nai no wa kokoro ga itamu.

abduction issue NOM show.progress-NEG NML TOP heart NOM hurt

'It is painful that the abduction issue is not showing progress.'

Both Sunakawa and Kamio examine written registers. Mori (2014), on the other hand, investigates the use of clefts in informal conversations under the conversation analytic framework. Mori's study only considers instances of no-wa clefts with nominalized clauses, followed by the copula da or its variants, in the comment position. She reports that 'well-formed' cleft constructions never appear in her conversational data. The following three types of no-wa cleft found in her conversational data all represent 'ill-formed' cleft constructions from the perspective of prescriptive grammar. In the following excerpts, taken from Mori (2014), the coparticipant's backchannel is presented in the parentheses.

(9a) ends with the reappearance of the same lexical item used in the topic clause (yana no wa ... iya-desu 'what I don't like most ... I don't like'). (9b) ends with a similar lexical item used in the topic clause (omotta no wa ... kanjita 'what I thought was ... I felt'). (9c) represents a case in which the no-wa topic clause is not accompanied by any clear grammatical marking that indicates the end of the corresponding comment component (omotteru no wa ... to 'what I think ... that').

(9) III-formed no-wa clefts (Mori 2014:194-196; modified by the author) ${ }^{4}$

(a) ただ私が一番やなのは, .hh 受け入れる時は期待と:: .hh やあ: あの新しい方との 出会いでね?（はい）すごく楽しいですけど, .hhh 帰る時が嫌ですねやっぱり.

tada watashi ga ichiban ya-na no wa, .hh ukeireru toki wa kitai to:: .hh ya: ano but I NOM most unpleasant-ATT NML TOP accept time TOP expectation and um atarashii kata to no deai de ne? (hai) sugoku tanoshii desu kedo, .hhh kaeru toki new person with GEN encounter COP PP yes really fun COP but return time ga iya desu ne yapari. NOM unpleasant COP PP expectedly

'... but what I hate most is, when I take them in, (I'm) full of anticipation and it's exciting meeting new people, right? (Yes.) so it's really fun, but I hate it when they go home, as you might expect.'

(b) 私が思ったのは, 日本が, アメリカかぶれしてるのと一緒で::, 韓国も::, (0.5) 日本 かぶれしてるみたいな所を感じた所があるのね,

watashi ga omot-ta no wa, nihon ga, amerikakabureshite-ru no to issho de::, I NOM think-PST NML TOP Japan NOM Americanized-ASP NML with same COP kankoku mo:., (0.5) nihonkabureshite-ru mitaina tokoro o kanji-ta tokoro ga aru Korea also Japanized-ASP like aspect ACC feel-PST aspect NOM exist no ne,

\footnotetext{
${ }^{4}$ See Appendix for transcription conventions for spoken data.
} 
SE PP

'What I thought was, like in the same way in which Japan has been Americanized, Korea, too has been Japanized, there are things that I felt that way.'

（c） ただ私自身が思ってるのはね, 先生たちにも言うんですが, .hhh一時間中を評価 のために授業をするんじやないよと.

tada watashi jishin ga omotte-ru no wa ne, senseitachi ni mo iu-n desu ga, .hhh but I self NOM think-ASP NML TOP PP teachers DAT also say-SE COP but ichijikanjuu o hyooka no tame ni jugyoo o suru-n ja nai yo one-hour-entire ACC assessment GEN purpose for class ACC do-SE COP NEG PP to.

QT

'... but what I myself think is, I tell other teachers this, too, but it is not that we design the entire class hour just for the purpose of assessment.'

Mori's study uncovers how no-wa topic clauses (i.e. [clause] no-wa) are used in response to a specific interactional need in a particular sequential context, and how they are treated by the participants themselves. For example, in the following sequence (10), Eri's utterance (lines 16-18) beginning with the no-wa topic clause (line 16) is treated by the co-participant Mari as not complete, despite Eri's use of the tag-like expression janai (line 18), which can be interpreted as the end of a turn in other contexts. Mari's understanding of Eri's turns as not being complete can be seen in her use of the minimal token $u:::: n$ 'uh-huh.'

(10) (Mori 2014:204-205; originally numbered [9])

16 Eri: そういーすごい最初:: すっごいびっくりしたのは:..., .hh

17 なんだろ, 夜中の十二時とか二時とかまでー

18 図書館 おおー(0.3) オープ[ンしてるじゃな::い..hhh=

19 Mari: [う::::ん

16 Eri: sooi-sugoi saisho:: suggoi bikkurishi-ta no wa::.: .hh

that really first really surprise-PST NML TOP

17

nan daro, yonaka no juuniji toka niji toka made-

what MOD midnight GEN 12-o'clock or 2-o'clock like until

18

toshokan oo- (0.3) oopu[nshite-ru ja-na::i. .hhh=

library open-ASP COP-NEG

'That- what really surprised me first is, how can I say, like until 12

o'clock midnight or 2 o'clock, libraries are o- open, aren't they?'

19 Mari: [u::::n

uh-huh

'Uh huh.'

Mori argues that the no-wa topic clause, such as the one in line 16 above, is used to initiate and project a forthcoming extended talk or multiunit turn. In particular, the no-wa topic clause functions as a 'prospective indexical' (Goodwin, 1996) which pre-announces the nature of the forthcoming extended talk and provides recipients with an interpretive framework. In the excerpt 
above, it is not until Eri produces a predicate similar to the one in the no-wa topic clause (sugoi naa:: toka omotta 'I thought that was impressive' (not shown)) that Mari treats Eri's turn as complete.

Mori speculates that the prescriptive grammar concerning cleft construction is based on written data and introspection. Rudimentary forms in conversation may represent more natural and basic usage (e.g. Pawley and Syder, 1983; Hopper, 2004). She argues that what looks like the partial fragment of the 'full' cleft construction, the no-wa topic clause, is a full-fledged construction used by conversational participants. However, we can also argue that the reason the no-wa topic clause functions the way it does in conversations is precisely because the coparticipants see it as a part of a fuller construction and they expect the latter half of the construction (i.e. comment) to be expressed. This view, taken in the present paper, allows for seeing and examining potential links and similarities among different forms and functions of the no-wa cleft (and related forms) used in different contexts.

The findings from the discourse-oriented studies reviewed above clearly show that the nowa cleft construction bears different forms and functions in different registers, which are likely to be linked to the communicative needs and purposes of particular contexts. The present study examines the no-wa cleft in multiple registers to provide a larger and more comprehensive picture of the use of this construction in Japanese. By examining different registers, we can survey a fuller range of forms and functions of the no-wa cleft. All instances of the construction found in the present data, including those that may look like incomplete pieces (or a different construction, Mori, 2014), are analyzed as being part of the family of the no-wa cleft, which are related to one another via partial formal and functional resemblances.

\section{Data and method}

The data set for this study comes from the following sources. News reports (News) and newspaper editorials (Editorials) are taken from four major newspaper online sites. ${ }^{5}$ Informal conversation data (Conversations) contain both face-to-face conversations and phone conversations between friends and family members. ${ }^{6}$ Academic presentation data (Presentations) come from recorded conference presentations in the field of engineering and those within the humanities and social sciences. ${ }^{7}$ To obtain a comparable data set, approximately the same number of texts/transcripts were drawn for each register. I used MeCab ${ }^{8}$ for morphological tokenization and AntConc ${ }^{9}$ for concordance. Table 1 displays the composition of each register.

\section{Table 1. Composition of the four registers}

\footnotetext{
${ }^{5}$ Specific data sources are as follows: Asahi Shimbun, retrieved from: www.asahi.com; Mainichi Shimbun, retrieved from: mainichi.jp; Sankei Shimbun, retrieved from: www.sankei.com; Yomiuri Shimbun, retrieved from: www.yomiuri.co.jp. 30 news reports and 25 editorials were retrieved from each site between September and October, 2017. The news reports come from the following categories: society (shakai), politics (seiji), business/economy (keizai), international affairs (kokusai), and sports. Editorials are called shasetsu in Asashi, Mainichi, and Yomiuri, and shuchoo in Sankei.

${ }^{6}$ Conversation data consist of the following corpora: 71 phone conversations from CallHome Japanese Corpus (Linguistic Data Consortium 1996); 41 face-to-face conversations from Sakura Corpus in the TalkBank database (14) (MacWhinney, 2007), Workplace corpus (14) (Women's language at the workplace and Men's language at the workplace, Gendai Nihongo Kenkyukai, 1997, 2002), and Japan Corpus (13) (Aoki et al., unpublished data).

7 Presentation data come from the Corpus of Spontaneous Japanese (National Institute for Japanese Language and National Institute of Information and Communication Technology, 2004).

${ }^{8}$ Kudo, Taku (2013) MeCab (Version 0.996). Available from: taku910.github.io/mecab.

${ }_{9}^{9}$ Anthony, Laurence (2014). AntConc (Version 3.4.4w) [Software]. Tokyo, Japan: Waseda University. Available from: www.laurenceanthony.net/software.
} 


\begin{tabular}{|l|r|r|r|r|}
\hline & News & Editorials & Conversations & Presentations \\
\hline Texts/transcripts & 120 & 100 & 112 & 108 \\
\hline Words (morphemes) & 27,731 & 55,781 & 228,484 & 353,852 \\
\hline Words per text (average) & 231 & 558 & 2,040 & 3,276 \\
\hline
\end{tabular}

The four registers were chosen for the present study because (aside from their availability) they represent different sets of situational characteristics. In terms of the channel of communication, News and Editorials both belong to written medium, while Conversations and Presentations belong to spoken medium. With respect to the plannedness of discourse, News, Editorials, and Presentations are all planned, to a varied degree, while Conversations is largely unplanned, due to its spontaneous nature. Regarding communicative purposes, News is the only register among the four that conveys solely factual information, whereas the other three also express opinions and evaluative stances.

In each register, all sentences containing the no-wa sequence in the concordance list were manually checked and non-cleft constructions, as well as clefts appearing within quoted speech or writing, were excluded from further analysis. Table 2 shows the number of no-wa clefts found in each register.

Table 2. Frequency of the no-wa cleft in the four registers

\begin{tabular}{|c|c|c|c|c|}
\hline & News & Editorials & Conversations & Presentations \\
\hline No. of no-wa clefts & 6 & 61 & 25 & 129 \\
\hline $\begin{array}{l}\text { No. of no-wa clefts per } \\
10,000 \text { words }\end{array}$ & 2.2 & 10.9 & 1.1 & 3.6 \\
\hline $\begin{array}{l}\text { No. of no-wa clefts per } \\
\text { text }\end{array}$ & 0.05 & 0.61 & 0.22 & 1.20 \\
\hline $\begin{array}{l}\text { No. of text with at least } \\
\text { one no-wa cleft }\end{array}$ & $6 / 120(5 \%)$ & $45 / 100(45 \%)$ & $\begin{array}{r}23 / 112 \\
(20.5 \%) \\
\end{array}$ & $\begin{array}{r}64 / 108 \\
(59.3 \%) \\
\end{array}$ \\
\hline
\end{tabular}

The no-wa cleft appears most frequently in Presentations, followed by Editorials, both with respect to the average number per text and the number of texts containing at least one no-wa cleft token. Normalized frequency is higher for Editorials than for Presentations; this is due to the relatively short length of editorial texts (558 words) compared with that of academic presentations (3,276 words). The no-wa cleft also appears in Conversations, although not as frequently as in Presentations and Editorials. Compared with these three registers, the no-wa cleft rarely appears in News.

All instances of the no-wa cleft in the four registers were examined from grammatical and functional perspectives. First, the grammatical properties of each no-wa cleft were investigated, focusing on the forms appearing in the comment position (Section 4.1). We find that spoken registers contain cases where the comment portion is only loosely connected to the no-wa topic clause. Nevertheless, observed similarities between more loosely and tightly connected forms warrant treating them as belonging to the same construction family. A comparative analysis of discourse functions performed by the construction in its varied forms (Section 4.2) further explicates how these forms and functions are related to each other.

\section{Findings and analyses}


Detailed examination of the no-wa cleft in the four registers, as presented in this section, reveals that formal similarities are related to the degree of plannedness in discourse production, while functional similarities are associated with communicative needs and purposes of the immediate discourse environments. Various functions identified and described in Section 4.2 can be broadly categorized into two general functional properties of the construction: a highlighting function at the local level and a (retrospective) anticipatory function at the global level (see Hopper, 2001).

\subsection{Grammatical properties}

In this section, the grammatical properties of elements immediately following no-wa are examined. As shown in Table 3, there is a major division between written registers (News and Editorials) and spoken registers (Conversations and Presentations). Most notably, in spoken registers, independent clauses and complement clauses frequently appear after no-wa, while in written registers, these types of clauses never appear in the comment position of the no-wa cleft.

Table 3. Grammatical properties of the elements following no-wa (comment position)

\begin{tabular}{|l|r|r|r|r|}
\hline & \multicolumn{1}{|l|}{ News } & \multicolumn{1}{l|}{ Editorials } & \multicolumn{1}{l|}{ Conversations } & \multicolumn{1}{l|}{ Presentations } \\
\hline Adverb (phrase) & $4 / 6(66.7 \%)$ & $6 / 61(9.8 \%)$ & $0 / 25(0 \%)$ & $2 / 129(1.6 \%)$ \\
\hline Noun (phrase) & $2 / 6(33.3 \%)$ & $30 / 61(49.2 \%)$ & $10 / 25(40 \%)$ & $70 / 129(54.3 \%)$ \\
\hline Adverbial clause & $0 / 6(0 \%)$ & $7 / 61(11.5 \%)$ & $2 / 25(8 \%)$ & $4 / 129(3.1 \%)$ \\
\hline $\begin{array}{l}\text { Nominal clause } \\
\text { Clause }\end{array}$ & $0 / 6(0 \%)$ & $18 / 61(30.0 \%)$ & $1 / 25(4 \%)$ & $14 / 129(10.9 \%)$ \\
\hline $\begin{array}{l}\text { Independent } \\
\text { clause }\end{array}$ & $0 / 6(0 \%)$ & $0 / 61(0 \%)$ & $2 / 25(8 \%)$ & $5 / 129(3.9 \%)$ \\
\hline \begin{tabular}{l} 
Total \\
\hline
\end{tabular} & $0 / 6(0 \%)$ & $0 / 61(0 \%)$ & $10 / 25(40 \%)$ & $34 / 129(26.4 \%)$ \\
\hline
\end{tabular}

In News, the only elements found in the comment position are single words or short nominal or adverbial phrases. In Editorials, about $60 \%$ of the no-wa clefts contain single words or phrases and the other $40 \%$ contain adverbial or nominal clauses in the comment position. As we can see in examples (11)-(13) below, compared with News, Editorials tend to have longer and more complex information in the comment position.

(11) News: adverb in the comment position

国連トップ就任後、グテレス氏が日本メディアの単独インタビューに㐫じたのは初めて。

kokuren toppu shuunin-go, guteresu-shi ga nihon media no tandoku intabyuu ni U.N. top inauguration-after (name)-Mr. NOM Japan media GEN exclusive interview DAT ooji-ta no wa hajimete.

respond-PST NML TOP first

'It was the first time Mr. Guterres responded to an exclusive interview with the Japanese media since being sworn in as the head of the United Nations.' 
(12) Editorials: noun phrase in the comment position 作品の根底にあるのは、日英の情感の融合だろう。

sakuhin no kontei ni aru no wa, nichiei no jookan no yuugoo daroo.

work GEN basis DAT exist NML TOP Japan-Britain GEN sensitivity GEN fusion MOD

'It is probably the fusion of Japanese and British sensitivities that is the basis of his work. / What is at the basis of his work is probably the fusion of Japanese and British sensitivities.'

(13) Editorials: nominal clause in the comment position

大切なのは、教師が何でも抱え込む慣行を見直すことだ。

taisetsu-na no wa, kyooshi ga nandemo kakaekomu kankoo o minaosu koto da.

important-ATT NML TOP teacher NOM anything take.on custom ACC reexamine NML COP

'What is important is to reexamine the customary practice of teachers taking everything upon themselves.'

As mentioned above, no-wa clefts with complement clauses and independent clauses in the comment position only appear in spoken registers in the present data. These clefts can be considered loose or disjointed. From researchers' perspectives, comment parts in disjointed nowa clefts may not be syntactically identifiable, but in actual interaction, interlocutors anticipate and treat these complement and independent clauses as pragmatically linked to the no-wa topic clause. On the other hand, no-wa clefts with nominal or adverbial phrases or clauses in the comment position form structurally tight unit. I call this type integrated clefts. The next table shows the distribution of integrated vs. disjointed no-wa clefts in the four registers.

Table 4. Distribution of integrated and disjointed no-wa clefts

\begin{tabular}{|l|l|l|l|l|}
\hline & News & Editorials & Conversations & Presentations \\
\hline Integrated & $6 / 6(100 \%)$ & $61 / 61(100 \%)$ & $13 / 25(52 \%)$ & $90 / 129(69.8 \%)$ \\
\hline Disjointed & $0 / 6(0 \%)$ & $0 / 61(0 \%)$ & $12 / 25(48 \%)$ & $39 / 129(30.2 \%)$ \\
\hline
\end{tabular}

In Conversations and Presentations, a substantial number of the no-wa clefts are of the disjointed type. The disjointed cleft can be further categorized as those that contain grammatical elements in the comment position that clearly indicate the end of the unit and those that do not contain such elements.

Within the first type, some clefts end with a quote marker (complement clause), and others end with either the same or a similar item as the one used in the topic position. (14) is an example of a disjointed cleft ending with a quote marker in Conversations. The co-participant's backchannels are shown in the parentheses.

(14) Conversations: disjointed cleft with complement clause in the comment position でもだか彼女達が言ってたのは:: 働いても: 結局（うん）英語がどうしても必要になったりとか (うん）ボスが (.) 外人がアメリカ人が多いんだって:

demo daka kanojotachi ga itte-ta no wa:: hataraite mo: kekkyoku (un) eigo ga dooshitemo but so (truncated) they NOM said NML TOP work after.all even English NOM inevitably hitsuyoo-ni nattari toka (un) bosu ga (.) gaijin ga amerikajin ga ooi-n da tte:: 
necessary-ADV become like boss NOM foreigner NOM American NOM many-SE COP QT

'But so what they said was that they end up needing English after working for a while, or their bosses often turn out to be foreigners- Americans.'

In spoken language, quote markers such as tte are often used in isolation without a corresponding communication predicate such as itte-ta '(they) said' to express quoted speech. Thus, a modified version of (14) without the predicate itte-ta '(they) said' is possible without causing any ambiguity. In (14), kanojotachi 'they' refers to the speaker's classmates from Thailand. The speaker and her interlocutor have been talking about these classmates in the immediately preceding context, so the subject of the utterance is clear without overt mention. This suggests that the no-wa clause in (14) (kanojotachi ga itte-ta no wa) is structurally rather independent from the rest of the utterance.

(14') Modified written version of (14)

（でもだか）働いても結局英語がどうしても必要になったりとかボスが外人がアメリカ人が多 いんだって.

(demo daka) hataraite mo kekkyoku eigo ga dooshitemo hitsuyoo-ni nattari toka bosu but so (truncated) work after.all even English NOM inevitably necessary-ADV become like boss ga gaijin ga amerikajin ga ooi-n da tte.

NOM foreigner NOM American NOM many-SE COP QT

'(But so they) said they end up needing English after working for a while, or their bosses often turn out to be foreigners- Americans.'

The second type of disjointed cleft with end-of-unit grammatical elements repeats the same or a similar predicate in the comment position. (15) and (16) are examples of this type. Just like (14), (15) and (16) would still make sense and convey the same information without the no-wa topic clause. This, again, implies that the no-wa clause is produced separately from the rest of the utterance. We can also notice that in both cases there are noticeable pauses immediately after the no-wa (with the pragmatic particle ne in the case of (15)).

(15) Conversations: the same predicate あの電話したのはね (0.3)（うん）あの: (0.6) 末永く友達でいたいなと思ったりして電話したん ですよ.

ano denwashi-ta no wa ne (0.3) (un) ano: (0.6) suenagaku tomodachi de i-tai na to omot-tarium called NML TOP PP (uh-huh) um forever friend COP stay-want PP QT think-suchshite denwashi-ta-n desu yo. do call-PST-SE COP PP

'The reason I called is (Uh-huh.) I called thinking I wanted to stay friends with you for many years to come.'

(16) Presentations: similar predicate ここで発話と言っているのは:: (0.4) 三百ミリ以上の (0.7) え: 無声区間で自動切り出しされた (0.3) その部分を (.) 発話と呼んでいます.

koko de hatsuwa to itte-iru no wa:: (0.4) 3-byaku miri ijoo no (0.7) e: museikukan de 
here LOC vocalization QT Say-ASP NML TOP 3-hundred millisecond um more.than um pause by jidoo kiridashis-are-ta (0.3) sono bubun o (.) hatsuwa to yonde-i-masu.

automatic cut.out-PSS-PST that part ACC vocalization QT call-ASP-POL

'What we are calling vocalization is, we are calling vocalization the parts that were cut out automatically between pauses of three hundred milliseconds or longer.'

The cases discussed so far all contain grammatical elements in the comment position that indicate the end of the unit.

There are other disjointed clefts, which do not contain any elements that indicate the unit ending. In a conversation in (17), speaker A's no-wa clause in line 1 is followed by a partial comment clause in the continuing te-form in line 3, but the trajectory of the talk gets diverted as speaker B begins to talk about the type of car she wants to buy in line 6 . In the subsequent segment (not shown), they continue to talk about different car models before they shift to a different topic. In the academic presentation in (18), the no-wa topic clause is followed by a long complex clause (... jittai de-arimasu 'is the fact'), but the comment of the topic clause, that is, one more thing the speaker wants to say, continues over another eight clauses (not shown).

(17) Conversations: disjointed cleft with no end marking

1. A: ちょっと俺ではね計画してんのはあっ子が:

2. B: うん.

3. A: 来たらあっ子も車買って:,

4. B: うん.

5. A: うんそんで，

6. B: あっ子チェロキーがいいよ.

7. A: うん?

1. A: chotto ore de wa ne keikakushite-n no wa akko ga:, little I and TOP PP plan-ASP NML TOP (name) NOM 'What I'm planning is you,'

2. B: un. uh-huh 'Uh-huh.'

3. A: ki-tara akko mo kuruma katte:, come-if (name) also car buy 'If you come, you also buy a car and,'

4. B: un. uh-huh 'Uh-huh.'

5. A: un sonde, yeah and 'Yeah and,'

6. B: akko cherokee ga ii yo. (name) Cherokee NOM good PP 'I want a Cherokee.'

7. $\mathrm{A}$ : un?

yes

'Huh?'

(18) Presentations: disjointed cleft with no end marking 
それとえ: もう一つあの: 申し上げたいのはですねあの: 私達こういう仕事をずっとやっ-アナウ ンスの仕事でま日本語のある部分を担ってきておりますけれども研究者の方々とのお: 現場と の交流というのは殆どないというのがあ: 残念ながら実態でありますえ:・・・

soreto e: moo hitotsu ano: mooshiage-tai no wa desu ne ano: watashitachi kooyuu shigoto o and um more one um say-want.to NML TOP COP PP um we this.kind work ACC zutto yat- anaunsu no shigoto de ma nihongo no aru bubun o ninatte-kite orimasu keredomo all.along do announce GEN work INS well Japanese GEN certain part ACC bear-ASP ASP but kenkyuusha no katagata to no o: genba to no kooryuu to yuu no wa hotondo nai to researcher GEN people with GEN um site with GEN exchange QT say NML TOP almost not.exist QT yuu no ga a: zannennagara jittai dearimasu e: ...

say NML NOM um unfortunately reality COP um

'And one more thing we want to say is um we have been working as announcers and we shoulder some part of Japanese language, but unfortunately the reality is that there is almost no exchange between researchers and on-site announcers um ...'

The three types of disjointed cleft resemble the prospective indexical no-wa topic clause found and discussed in Mori (2014), especially those in Conversations. Unlike what Mori found in her conversational data, however, both Conversations and Presentations also contain integrated forms of the no-wa cleft. This discrepancy is likely due to the fact that Mori's study only considers clefts with nominalized clauses in the comment position. ${ }^{10}$

Within the integrated types, the average number of words in the comment position shows differences among the four registers: 5.2 in News, 11.9 in Editorials, 3.6 in Conversations, and 10.6 in Presentations. (19)-(22) below are representative examples from the four registers. As the differences in the number of words in the comment position suggest, Editorials and Presentations contain much more complex information than News and Conversations. The former registers with more complex information contain more cases of no-wa cleft constructions (see Table 2).

(19) News: average of 5.2 words in the comment position (6 words in the example) 捜査本部によると、通報があったのは 8 日午前 6 時ごろ。

soosa honbu ni yoruto, tsuuhoo ga at-ta no wa yoo-ka gozen roku-ji investigation headquarter DAT according report NOM exist-PST NML TOP $8^{\text {th }}$-day a.m. 6-o'clock goro.

around

'According to investigation headquarters, it was around 6 a.m. on the $8^{\text {th }}$ when the report was made.'

(20) Editorials: average of 11.9 words in the comment position (11 words in the example) 肝心なのは、それぞれの投資案件について透明性を高めることである。

kanjin-na no wa, sorezore no tooshi anken ni tsuite toomeisei o takameru koto dearu. crucial-ATT NML TOP each GEN investment item DAT about transparency ACC increase NML COP

10 The present study found one example of a no-wa cleft with a nominal clause in Conversations (see Table 3). 
'What is important is to increase the transparency for each investment item.'

(21) Conversations: average of 3.6 words in the comment position (3 words in the example) あの大樹さんじゃなくて日本にいる集だったっけ?

ano daiki san ja-nakute nihon ni iru no wa dare dat-ta kke?

um (name) Mr. COP-NEG Japan DAT exist NML TOP who COP-PST PP

'Um, not Daiki, who was it that is in Japan?'

(22) Presentations: average of 10.6 words in the comment position (12 words in the example) え:今日お話したいと思いましたのはあ:: 判断を原則のレベルでえ:: 捉える (0.4) 為の (0.3) お:: 準備的な議論 (.) です.

e: kyoo ohanashishi-tai to omoi-mashi-ta no wa a:: handan o gensoku no reberu de um today talk-want.to QT thoink-POL-PST NML TOP um judgment ACC fundamental GEN level at e.: toraeru (0.4) tame no (0.3) o:: junbiteki-na giron (.) desu. um grasp purpose GEN um preliminary-ATT discussion COP

'Um, what (I) thought (I) wanted to talk today is a preliminary discussion for the purpose of understanding judgments at a fundamental level.'

In this section, we saw that spoken registers, regardless of formality, allow structural flexibility in the use of the no-wa cleft. Especially in conversations, in which co-participants actively participate in meaning making and negotiation, the no-wa topic clause may look independent from the rest of the utterances. However, the fact that co-participants usually anticipate and wait for the indication of the end of corresponding comment demonstrates that the entire structure is seen as a unit. The resulting form, when researchers transcribe and put them on paper, may seem ill-formed. But when the form is actually produced and interpreted in ongoing spoken discourse, interlocutors do not treat it as such. At the same time, the two spoken registers also contain integrated forms of the no-wa cleft. The next section examines motivations for the uses of construction in context and identifies their discourse functions in each of the four registers.

4.2 Discourse functions of the no-wa cleft in the four registers In this section, we examine context-dependent functions and motivations for the use of the nowa cleft in each register. We find that the no-wa cleft is used to perform a wide variety of functions, and those functions are closely linked to the communicative purposes and constraints found both within and across the registers. In News, it only has a single function of underlining temporal/numerical information (100\%). The other three registers contain several functions, listed here in order of frequency. Editorials include four functions: signposting main theses (83.6\%), presenting situational frameworks (6.6\%), presenting sequentially relevant information (4.9\%), and underlining 'first time' information (4.9\%). There are also four functions identified in Conversations: early projection (prospective indexical) (48\%), expressing contrast (20\%), performing repairs (16\%), and calling attention (16\%). Presentations have the largest number of functions: early projection (50.4\%), identifying a (sub-)topic (20.9\%), presenting major findings/significant information (17.1\%), presenting supplementary/background information (6.2\%), and expressing contrast (5.4\%).

\subsubsection{News (News reports)}


As we saw in the previous section, the no-wa cleft is very infrequent in News and its form is rather fixed. The limited nature of the no-wa cleft in News is also seen in the semantic property of information in the comment position. The two types of information found in the comment position are time (e.g. hajimete 'first,' zenkoku hatsu 'first in the country,' sotsugyoo shite kara 'after graduation,' 8-ka 'on the $8^{\text {th }}$,' gozen 6-ji goro 'around 6 a.m.') and the number of people (e.g. 5161-nin '5161 people,' 5-nin-me '5 ${ }^{\text {th }}$ person'). The no-wa cleft is used to underline a specific type of information. (11) and (19) presented in the previous section both have timerelated information in the comment position. (23) expresses the number of people involved in the reported event in the comment position.

(23) News: the number of people in the comment position 全国からの応募約 32 万件のうち、シャンシャンと応募したのは 5161 人だった。

zenkoku kara no oobo yaku 32-man-ken no uchi, shanshan to ooboshi-ta nationwide from GEN application approx. 32-million-case GEN within (name) QT apply-PST no wa 5161-nin dat-ta.

NML TOP 5161-people COP-PST

'There were 5,161 people who submitted Shanshan (for the panda's name) among three hundred twenty thousand submissions nationwide.'

As to the reason why the no-wa cleft is scarce in the News register, since its use for underlining some information implies taking a certain perspective, it does not fit the main purpose of news reports to objectively report factual information. The limited types of information that are used with the no-wa cleft, time and the number of people, are objective and verifiable, and they are usually not topicalized. With these types of information, the use of the no-wa cleft does not imply a subjective viewpoint of the writer. Thus, the construction is used rather formulaically to organize information locally, and it also adds sentence variety to the monotonous news reporting text.

\subsubsection{Editorials}

Editorials is one of the two registers in which the no-wa cleft frequently appears. We might expect, since both News and Editorials are newspaper texts, that the no-wa cleft plays similar roles in the two registers. Although the function of underlining temporal information is also found in Editorials, this function accounts for only 3.3\% (2/61) of all the no-wa clefts in this register (and both cases have hajimete 'for the first time' in the comment position). Instead, a majority of the no-wa clefts in Editorials (83.6\% or 51/61) are used in relation to the main point of the article. That is, the no-wa cleft is used to state the main thesis of the article (19/51), to present key information supporting the main point (23/51), or to present information that is highly relevant to the main point $(9 / 51)$.

The main point expressed in the no-wa cleft is often a paraphrase or a further explication of the information expressed in the title of an article. In (24) (the same as (13)), the no-wa cleft expresses the thesis of the article, which is also a paraphrase of the title shown in the parentheses. In (25) (the same as (12)), the no-wa cleft expresses the main point of the article, which is a further explication of the title shown in parentheses. Many of the no-wa clefts expressing the point of an article include evaluative elements in the topic position (78.9\% or 15/19). The most common element is juuyoo-na no wa 'what is important,' followed by kanjin-na no wa 'what is important.'

(24) Editorials: main point (paraphrase of the title) 
大切なのは、教師が何でも抱え込む慣行を見直すことだ。

(教師の過労対策＼cjkstart雑務を抱え込む慣行なくそう)

taisetsu-na no wa, kyooshi ga nandemo kakaekomu kankoo o minaosu koto da.

important-ATT NML TOP teacher NOM anything take.on custom ACC reexamine NML COP

"What is important is to reexamine the customary practice of teachers taking everything upon

themselves.'

(kyooshi no karoo taisaku zatsumu o kakaekomu kankoo nakus-oo)

teacher GEN overwork measure routine.duties ACC take.on custom eliminate-VOL

('Teachers' overwork measures: let's eliminate the customary practice of (teachers) taking on

routine duties')

(25) Editorials: main point (further explication of the title)

作品の根底にあるのは、日英の情感の融合だろう。

(ノーベル文学賞 頂点極めたイシグロ氏の情感)

sakuhin no kontei ni aru no wa, nichiei no jookan no yuugoo daroo.

work GEN basis DAT exist NML TOP Japan-Britain GEN sensitivity GEN fusion MOD

'It is probably the fusion of Japanese and British sensitivities that is the basis of his work. / What is at the basis of his work is probably the fusion of Japanese and British sensitivities.'

(nooberu bungaku shoo chooten kiwame-ta ishiguro shi no jookan)

Nobel literature award summit reach-PST (name) Mr. GEN sensitivity

(Nobel Prize for literature Sensitivities of Mr. Ishiguro who reached the summit)

When a no-wa cleft itself does not express the main thesis, it often presents key evidence or information supporting the main thesis (as in (26)) or information that is highly relevant to the main point (as in (27)). As seen in the next example (26), main points are often expressed in the title as well as toward the end of an article (see Nishihara, 1997). In (26), the main point, that the U.S. cannot reinforce stricter gun controls and that this is a weakness, is expressed in the title shown in the parentheses and also in the last sentence of the article shown within the square brackets. What is expressed in the no-wa cleft is the key information which supports this main point.

(26) Editorials: key information supporting the main point

衝撃的なのは、大量のライフルなどの銃器や弾薬、スコープ（照準器）、銃を固定する三脚が

部屋から見つかったことだ。

(ラスベガス乱射銃規制強化できぬ米国の病弊)

[残念ながら、銃規制の稂格化は望めまい。社会の分断が一段と深まることも懸念される。米国 の病弊と言えよう。]

shoogekiteki-na no wa, tairyoo no raifuru nado no juuki ya danyaku, sukoopu (shoojunki), juu o shocking-ATT NML TOP a.lot GEN rifle such.as GEN firearm and ammunition scope sights gun ACC koteisuru sankyaku ga heya kara mitsukat-ta koto da.

stabilize tripod NOM room from be.found-PST NML COP

'What is shocking is that a large amount of firearms and ammunition such as rifles, scopes

(sights), and tripods which stabilize the guns were found in the room.'

(rasubegasu ransha juu kisei kyooka deki-nu beikoku no byooheki) 
Las Vegas random.firing gun control reinforce can-NEG U.S. GEN morbid.habit (Las Vegas random shootings: the weakness of the U.S. which cannot reinforce gun controls)

[zannennagara, juu kisei no genkakuka wa nozome-mai. shakai no bundan ga ichidanto unfortunately gun control GEN reinforcement TOP expect-NEG society GEN divide NOM further fukamaru koto mo kenens-areru. beikoku no byooheki to ie-yoo.] deepen NML also fear-PSS U.S. GEN morbid.habit QT can.say-VOL ['Unfortunately, we cannot expect gun control reinforcement. It is also feared that society will be further divided. It (the current situation) can be called a weakness in the U.S.']

(27) is on with the same topic as (25), but it comes from a different editorial article and newspaper than (25). The main point of this editorial, as expressed in the title shown in the parentheses, is that Mr. Ishiguro's Nobel Laureateship is a good opportunity for Japanese people to reconsider their own country and culture. The no-wa cleft expresses information that is highly relevant to the main thesis. The cleft construction appears immediately after the sentence expressing the main point (now shown).

(27) Editorials: information highly relevant to the main point ... むしろ感謝するのは日本の方だ。

(イシグロ氏受賞 日本を見つめ直す契機に)

mushiro kanshasuru no wa nihon no hoo da.

rather be.grateful NML TOP Japan GEN side COP

'... rather, it is Japan that should be grateful (to Mr. Ishiguro).'

(ishiguro shi jushoo nihon o mitsumenaosu kikai ni)

(name) Mr. prize.winning Japan ACC reconsider opportunity DAT

(Mr. Ishiguro winning prize An opportunity to reconsider Japan)

Besides the major function of indicating the high relevance of information to the main point of an article, the no-wa cleft in Editorials also has the functions of presenting situational frameworks (6.6\% or 4/61), presenting sequentially relevant information (6.6\% or 4/61), and underlining temporal ('first time') information (3.3\% or 2/61). Notably, Editorials is the only register that has the function of presenting situational frameworks, as Sunakawa $(1995,2005$, 2007) found in her essay and novel data. The shared function between Editorials and essays/novels suggests that these registers share some situational or communicative characteristics in common. We will come back to this point in Section 5.

To summarize, a majority of the no-wa clefts in Editorials are used as main thesis reference points. This major function as well as the function of presenting situational frameworks are motivated by concerns related to text organization. Editorials is a type of persuasive writing with dense information dispersed across many short paragraphs. The no-wa cleft seems to be mainly used as a discourse organizational device to structure the text around the main argument of the writer and draw readers' attention to it.

\subsubsection{Conversations (informal conversations)}

The disjointed cleft, presented in the previous section, represents one major type of the no-wa cleft in Conversations. The no-wa topic clause is used to project a longer unit of talk (comment part), and by doing so, it functions to secure the speaker's floor and provide the addressee with a general interpretive framework to understand and participate in the subsequent talk (i.e. prospective indexical). About half of the no-wa clefts in Conversations are of this type (48\% or 
12/25). In (28) (the beginning part of (17)), A uses the no-wa topic clause in line 1 to secure his floor, and B shows her understanding of such projection in the uses of the continuer un 'yeah' in lines 2 and 4 (although the talk eventually digresses and shifts to a different topic as we saw in (17)). The anticipatory use of the no-wa clause tends to co-appear with the pragmatic particle ne 'you know' and the first person pronouns such as ore 'l' in (28) (see also conversational examples from Mori (2014) in (9a)-(9c) above). It has been suggested that the use of ne is associated with the floor-holding function (Cook, 1992; Ono and Thompson, 2003) and the use of first person pronouns is linked to the 'frame-setting' function (Ono and Thompson, 2003), which is similar to the function of prospective indexical.

(28) Conversations: projection

1. A: ちょっと俺ではね計画してんのはあっ子が:,

2. B: うん.

3. A: 来たらあっ子も車買って:,

4. B: うん.

1. A: chotto ore de wa ne keikakushite-n no wa akko ga:, little I and TOP PP plan-ASP NML TOP (name) NOM

2. B: un.

uh-huh

'Uh-huh.'

3. A: ki-tara akko mo kuruma katte:, come-if (name) also car buy 'If you come, you also buy a car and,'

4. B: un.

uh-huh

'Uh-huh.'

Contrary to the extended and multi-unit nature of the disjointed prospective indexical no-wa cleft, integrated forms of the cleft in Conversations are short in length and produced in single intonation units. While disjointed no-wa clauses work to foreshadow upcoming talk, integrated no-wa clefts deal with ongoing meaning making and negotiation processes. In particular, three functions are identified: calling attention ( $16 \%$ or $4 / 25)$, expressing a contrast (20\% or $5 / 25)$, and doing a repair ( $16 \%$ or $4 / 25)$. These functions are by no means exclusive to the no-wa cleft, but the construction serves as one resource to perform these conversational actions. (29)-(31) represent each of these functions.

In (29), the speaker A suggests two freight companies for $B$ to send packages. In lines 1 and $3, A$ begins to formulate a comparative sentence (company $X$ or company $Y$ ), but after clarifying the name of the first company in line 5 , she abandons the comparative sentence and utters a new superlative sentence using the no-wa cleft in line 7. Sequentially, she could have completed the comparative sentence by just giving the name of the second company and providing a predicate ((kakimata-unyu tte yuu tokoro ka) $A B C$ ga ii '(the place called kakimataunyu or) $A B C$ would be good.') Instead, the speaker uses the no-wa cleft to call the addressee's attention to the second company $(A B C)$. In the subsequent context (not shown), the two interlocutors only discuss the second company.

(29) Conversations: calling attention

1. A: 荷物送るんだったら:,

2. B: うん. 


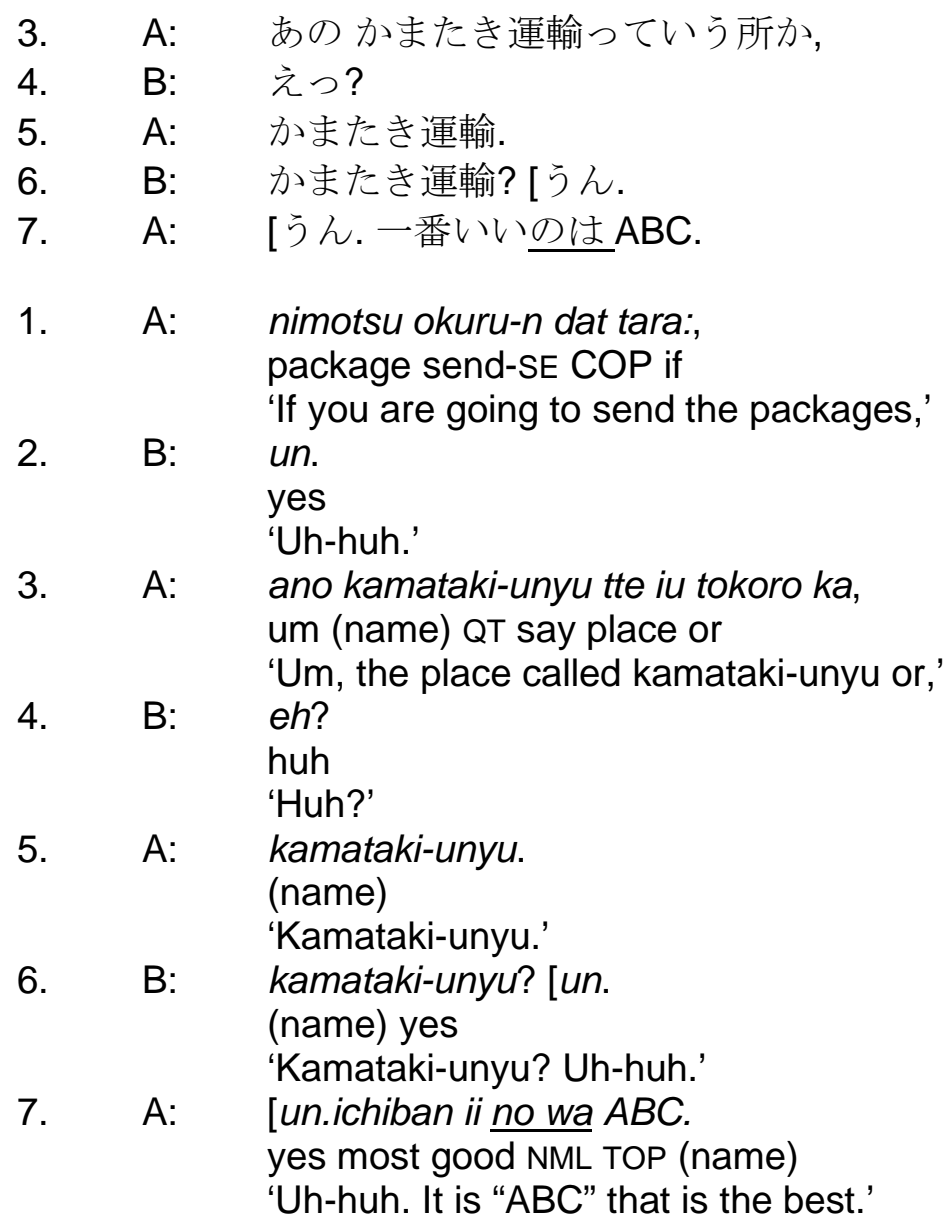

In the preceding context to the shown segment in (30), speaker B asked A about the location of the prep school A is thinking of going. In line 1, A begins to answer B's question by providing information that there are two types of institutions (or programs at different locations). In line 3, A uses the no-wa cleft to contrastively identify the institution/program he was admitted to (and thinking of going).

(30) Conversations: expressing a contrast
1. A: レックならね (1.0) 二種類あるんだ今.
2. B: ऊ::ん.
3. A： で俺の一個通ってんのは高田馬場 (.)の方だけど,
1. A: rekku nara ne (1.0) ni-shurui aru-n da ima. (name) if PP two-kind exist-SE COP now 'Lec has two kind (of institutions/programs) now.'

2. B: fu::n.

$\mathrm{hmm}$ 'Hmm.'

3. A: de ore no ik-ko tootte-n no wa takadanobaba (.) no hoo da kedo, and I GEN one-CLS pass-SE NML TOP (place) GEN side COP but 'And, it is the one at Takadanobaba that I was admitted to,' 
In (31), speaker A is telling B about the takoyaki (octopus dumpling) restaurant she saw on TV the day before. In the preceding segment, A mentioned that guests would grind white sesame seeds to be sprinkled on top of takoyaki. Then, in line 1, B checks her understanding that the guests sprinkle the sesame seeds by themselves. In line 2, A uses the no-wa cleft to correct B's misunderstanding and clarify that it is the restaurant's staff who does that.

(31) Conversations: doing a repair (other-initiated, self-repair in this example)

1. B: ふ::ん. みずからかけるんだ.

2. A： や: みずからかけんのはお店の人だけどね?

1. B: fu::n. mizukara kakeru-n da.

hmm by.oneself sprinkle-SE COP

'Hmm. The guest sprinkle (the sesame seeds) by themselves.'

2. A: ya: mizukara kaken no wa omise no hito da kedo ne?

no by.oneself sprinkle NML TOP restaurant GEN person COP but PP

'No, it is the restaurant staff that sprinkles (the sesame seeds).'

In summary, four discourse functions are found in Conversations: prospective indexical, calling attention, making contrast, and performing repair. All of these uses are motivated by interactional concerns of the speaker. Prospective indexical is motivated by the speaker's concerns for the addressee as an active co-participant in the ongoing talk, and the other three functions are motivated by concerns related to achieving shared understanding and affective stance between the speaker and the addressee.

\subsubsection{Presentations (Academic presentations)}

As described in Section 3, the no-wa cleft is used more frequently in Presentations and Editorials than in the other two registers. We have seen that, in Editorials, it is often used to signal information as highly relevant to the main thesis of the article. In Presentations, more than half of the no-wa clefts (50.4\% or 65/129) are used for the early projection function, which is similar to the prospective indexical function found in Conversations. Unlike Conversations, in Presentations, both disjointed and integrated forms of the no-wa cleft are used for this function. What seems to separate the two forms is the degree of plannedness. Speakers in this register have a freedom in how much and how well they prepare their presentations including preparing some type of script or notes. The following two segments, (32), an integrated type, and (33), a disjointed type, both have very long comment parts.

(32) Presentations: integrated cleft

えここであの数字を見るとお分かりになりますように大変特徽的なのは (0.4) 正答のリピート は(.) その教師の (0.2) 教師が入ったグループの方に多く (0.4) .hh 異なる正答の主張は (0.2) え: それに対し (.) 学習者同士の方にしか起こっていない(.) ということです.

e koko de ano suuji o miru to owakarininari-masu yooni taihen tokuchooteki-na no wa (0.4) um here um number ACC see if understand-POL as very characteristic-ATT NML TOP seitoo no ripiito wa (.) sono kyooshi no (0.2) kyooshi ga hait-ta guruupu no hoo correct.answer GEN repeat TOP that teacher GEN teacher NOM participate-PST group GEN side ni ooku (0.4) .hh kotonaru seitoo no shuchoo wa (0.2) e: sore ni taishi (.) gakushuusha dooshi DAT many different correct.answer GEN argument TOP um that DAT against learner each.other no hoo ni shika okotte-i-nai (.) to iu koto desu.

GEN side DAT only happen-ASP-NEG QT say NML COP 
'Um as you can see um the numbers, what is very characteristic is that repetition of the correct answer was seen more in the groups of teachers, with teachers, and the argument for different correct answers were only seen in groups with just students.'

(33) Presentations: disjointed cleft

で最後ちょっと人数が減ってるのは.hh あの::: (0.8) おっ (0.2) あの:: 何て言うんでしょう(.) ア ルバイトで来てもらってますので: .hh 時間がちょっと過ぎたりして最後の検査が: .hhh あの:時 間.hh オーバーしてるので申し訳ありませんで帅っていただいた為にちよっと最後減ってしま いました。

de saigo chotto ninzuu ga hette-ru no wa .hh ano::.: (0.8) o (0.2) ano:: nante iu-n dehsoo (.)and last little number.of.people NOM decrease-ASP NML TOP um oh um what say-SE MOD arubaito de kite-moratte-masu node: .hh jikan ga chotto sugitarishite saigo no kensa ga: .hhh part.time by come-get-POL because time NOM little pass last GEN experiment NOM ano: jikan .hh oobaashite-ru node moushiwakearimasen de kaette-itadai-ta tameni chotto saigo um time go.over-ASP because I.appologize and go.home-get-PST because little last hette-shimai-mashi-ta.

decrease-ASP-POL-PST

'And the reason why the number of people decreased at the end, um, oh, um, how do I say, because we had them come as part time work, it took too much time, the time exceeded the amount we had to do the last experiment, so I apologize, and because we had them go home, the number decreased.'

In the disjointed no-wa cleft (33), we see several fillers, re-starts, and a self-search. Though we also see a filler and a repair of a particle in the integrated cleft (32), the speaker of (33) seems to be talking more spontaneously than the speaker of (32). We can speculate that the speaker of the integrated cleft had a script or rehearsed the presentation, at least for the aforementioned portion. Despite these differences, the two examples share the function of early projection.

In Conversations the speakers use the no-wa topic clause to secure their floor and provide the addressee with an interpretive framework to understand and participate in the subsequent talk. In Presentations, on the other hand, the speakers do not have to secure their floor (as they are the sole speakers) and they do not have to involve the addressees, at least not in a direct manner. The speakers in Presentations use the no-wa cleft to state the main predicate early on, which enables the early projection of what is to follow and the main point of the current utterance. In a predicate-final language like Japanese, this early projection function (see Fox et al., 1996: 207-214) is especially useful in talking about complex ideas. The use of the no-wa cleft allows the speaker more flexibility in how the rest of the utterance unfolds as they do not have to keep in mind the appropriate predicate (i.e. the main point of the utterance), and this in effect lowers the speaker's cognitive load. ${ }^{11}$ The early projection no-wa cleft appears in all sections of the academic presentations: introduction, background, data and methodology, findings, discussion, and conclusion, which demonstrates the usefulness of the construction in this register. Among these sections, the early projection no-wa cleft appears most frequently in the findings section, which generally deals with the most dense and complex information. ${ }^{12}$

\footnotetext{
11 It also helps the audience in comprehending the unfolding talk on a complex topic, but the primary motivation for the use of the no-wa cleft is cognitive rather than interactional/interpersonal.

${ }^{12}$ Some speakers interpreted the results as they reported them. I categorized these cases as belonging to the result section rather than the discussion section of their presentations.
} 
As mentioned earlier in this section, the early projection function covers more than half of all no-wa clefts (50.4\% or 65/129) in Presentations. Examples that are not mainly used for early projection are used to identify a (sub-)topic (20.9\% or 27/129), present major findings/significant information (17.1\% or 22/129), present supplementary/background information (6.2\% or 8/129), and to express a contrast (5.4\% or $7 / 129)$. Some of these functions share some characteristics with those found in other registers. The function of expressing a contrast was also seen in Conversations. The function of identifying a (sub-)topic is not seen in other registers within the current data, but it was one of the major functions identified in Sunakawa's $(1995,2005,2007)$ essay and novel data.

Speakers in Presentations must deal not only with the temporal constraint of dynamic spoken language, as in Conversations, but also with the high cognitive load of delivering complex information on line. They are doubly concerned with lessening their cognitive load and presenting information as clearly as possible. The no-wa cleft seems to be a particularly useful grammatical/rhetorical resource to address these cognitive and presentational needs and concerns. In Presentations, the no-wa cleft is most commonly used to state the thrust of the current utterance early, and by doing so it lowers the cognitive load and warrants the speaker more time and flexibility in unfolding the rest of the utterance. The use of the no-wa cleft to identify (sub-)topics (and present background information) also helps with keeping the cognitive load low since the only new information is the (sub-)topic (or background information) and it allows the speaker more time to formulate the subsequent talk about the (sub-)topic (or the main part). The other uses of the no-wa cleft in Presentations seem to be motivated by the presentational concerns of the speaker to present information in a clear manner.

\section{Discussion}

As we saw in the previous section, various functions of the no-wa cleft construction are closely linked to the communicative purposes and needs of the registers. At the same time, some functions are found in more than one register and others share some characteristics. To see this more clearly and further explore their family resemblance relations, all functions identified from the four registers, as well as those found in the previous studies from essays and novels (Sunakawa, 1995, 2005, 2007), are listed under (34). The list is not meant to be exhaustive since it only reflects the set of data examined and analyzed in the present study. In parentheses, I indicate the functional level of the construction at work: local sentential level or global discourse level.

(34) Functions of no-wa cleft construction

News

- N1: Underlining temporal/numerical information (local)

\section{Editorials}

- E1: Main thesis signpost (global)

- E2: Situational framework (global)

- E3: Sequentially relevant information (local)

- E4: Underlining 'first time' information (local)

\section{Conversations}

- C1: Prospective indexical (global)

- C2: Calling attention (local/global)

- C3: Expressing contrast (local)

- C4: Performing repair (local) 
Presentations

- P1: Early projection (global)

- P2: Identifying (sub-)topic (local/global)

- P3: Presenting supplementary/background information (local/global)

- P4: Presenting major findings/significant information (local)

- P5: Expressing contrast (local)

Essays/novels

- EN1: Closing topic (global)

- EN2: Situational framework (global)

- EN3: Introducing topic (local/global)

As noted earlier in the paper, local-level functions can be loosely grouped together under the general function of highlighting information. Similarly, all global-level functions can be related to each other by the general anticipatory function. All individual functions that belong to the general highlighting information function (N1, E3, E4, C3, C4, P4, P5) show local concerns of presenting information clearly and effectively by highlighting information in the comment position. Functions that are categorized under the global-level anticipatory function (E1, E2, C1, P1, EN1, EN2) show concerns beyond sentential level. Prospective indexical (C1) and Early projection (P1) in spoken registers utilize the two parts of the construction, that is, the no-wa topic clause and the comment, more or less disjointedly to perform the anticipatory function. Others, which are all in written registers, use the entire construction as an integrated unit. Situational framework (E2, EN2) contains simple information in the comment position, and the expressed information in the comment position is discussed in the immediately subsequent context. Main thesis signpost (E1) and closing topic (EN1) represent cases of retrospective anticipation. For example, when the main point of an editorial article, indicated or implied in the title, is paraphrased or explicated using the no-wa cleft, the readers can be said to have anticipated this statement as they would expect this type of article to be developed around a main thesis. In the function of closing a topic in essays, the readers can also be said to have retrospectively anticipated the closing of the particular topic while reading the preceding discourse. In this way, the (retrospective) anticipatory function contributes to the organization of discourse at the global level.

Four functions (C2, P2, P3, EN3) have not been discussed. These functions seem to be at work at both local and global levels. They highlight information in the comment position as other local level functions do, but the information also becomes the topic of the immediately subsequent discourse (P2, EN3), or the information is closely tied to the subsequent discourse through a subordinating relationship (P3). In the case of 'calling attention' (C2), the information is proposed as something that merits further talk, and in many cases, it is continued to be discussed in the subsequent discourse (as we saw earlier in (28)). The dual functionality is similar to how discourse makers such as because can simultaneously perform functions at local and global levels (Schiffrin, 2001:57-58). (35) is an example of 'identifying (sub-)topic' function from Presentations (P2). In this example, the no-wa cleft isolates and highlights the information in the comment position (the writer's workshop that the speaker used to go to). However, this is not the only function the construction plays here; it also projects the content of subsequent discourse. In this and other examples of the identifying (sub-)topic function, the identified (sub-)topic is discussed in the immediately subsequent discourse. This parallels the global anticipatory function of the no-wa construction.

(35) Presentations: identifying (sub-)topic 
えこうした問題を耳に (0.2) するに付けて (.) 思い出すのは (0.3) 私がアメリカの大学院でよく 通った (.) ライターズワークショップ (.) です.hh で: このライターズワークショップは・・・

e kooshita mondai o mimi ni (0.2) suru ni tsukete (.) omoidasu no wa (0.3) watakushi ga um this.kind issue ACC ear DAT do DAT put remember NML TOP I NOM

amerika no daigakuin de yoku kayotta (.) raitaazu waakushoppu (.) desu .hh de: kono raitaazu America GEN graduate.school LOC often attend writer's workshop COP and this writer's waakushoppu wa ...

workshop TOP

'What I remember when I hear these kinds of problems is the writer's workshop I often went to at a graduate school in the U.S. And, this writer's workshop ...'

Fig. 1 visualizes family resemblance relations among individual register-oriented functions. The codes refer to the functions listed in (34). Functions found in each register are vertically aligned (except for News since it only contains one function). The large circle on the left represents a set of global anticipatory functions and the one on the right represents a set of local highlighting functions. The four functions at the center within the overlapping area of two large circles (EN3, P2, P3, C2) work at both local and global levels. The smaller ovals with labels indicate that these individual functions share certain characteristics and thus form clusters.

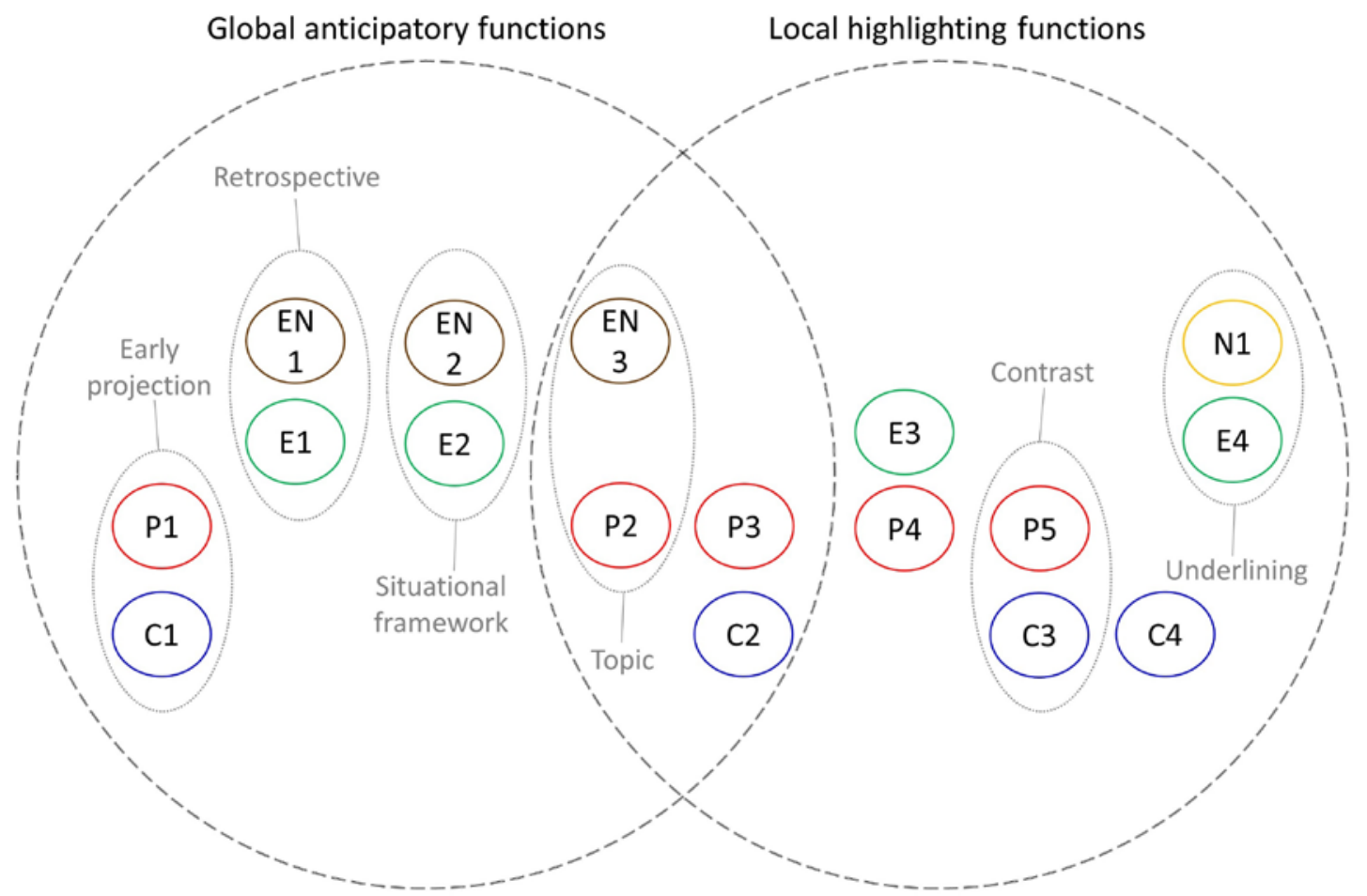

Figure 1. Family resemblance relations among the no-wa cleft functions

There are two clusters between Conversations and Presentations and between Editorials and Essays/novels, and one cluster between News and Editorials and between Presentations and Essays/novels. The clusters imply that the registers share similar communicative needs/purposes and/or situational characteristics/constraints. Both Conversations and 
Presentations, for example, have the temporal constraints of delivering and processing utterances on line, which make the early projection function of the no-wa cleft useful. Editorials and Essays/novels, which form the cluster of Situational framework, share the characteristics of monological, planned texts, written from certain perspectives. The two registers can also contain a story-like segment within a larger context. Even these clusters, however, only represent partial overlaps. In the case of the Early projection cluster, for instance, disjointed forms are used in Conversations to engage the co-participants, while both disjointed and integrated forms are used in Presentations to lessen the cognitive processing load of the speaker. As stated in the introductory section, no single feature is found in all members of a family and shared features are similar but not identical.

\section{Conclusions}

The no-wa cleft is most useful in non-objective discourse with a higher level of complexity. Among the four registers examined, all but News represent non-objective discourse. In Editorials, the complexity comes simply from the complexity of information. In Conversations, the complexity arises from the temporal constraints and the need to engage the co-participant. In Presentations, it derives from both the complexity of information and temporal constraints. This dual layer of the complexity in Presentations makes the no-wa cleft especially useful in this register. It is important to make clear that there is no direct link between any register and the use of no-wa cleft. What speakers and writers attend to are specific communicative purposes under certain constraints from the immediate discourse environment; the no-wa cleft is one of the pragmatic and rhetorical resources that serve these purposes. The connection between form-function pairings becomes more strengthened as they are used repeatedly. Thus, if a communicative need of a register is highly specific and limited, and the same form is used for a purpose over and over again, the form-function paring may end up becoming a defining characteristic of that register (e.g. count routines in sports announcers' talk discussed in Ferguson, 1983). This study did not find this to be the case for the use of the no-wa cleft in the four registers. The findings of this study support the view that form and register are mediated by register-independent communicative functions (Matsumoto, 2015).

Seen from the perspective of register studies, the present study also sheds light on how situational characteristics at different levels of generality may be related to one another (see Biber, 1994: 34). For example, editorials and essays/novels may represent higher-level contexts consisting of a set of co-appearing, but not exclusive, situational characteristics. One of the situational characteristics they share is that of planned written story or narrative, which is found to be linked to the Situational framework setting function of the no-wa cleft. More register-based studies on various linguistic features will provide further insights into the role of context, at various levels, in form-function associations.

\section{Acknowledgments:}

The author is grateful to the anonymous reviewers, whose comments and suggestions greatly improved the presentation of this paper. The author would also like to thank Michael Levine for language editing.

Appendix: Abbreviations and transcription conventions
Abbreviations
$\begin{array}{llllll}\text { ACC } & \text { accusative } & \text { MOD } & \text { modal expression } & \text { PP } & \text { pragmatic particle } \\ \text { ASP } & \text { aspect } & \text { NEG } & \text { negative } & \text { PSS } & \text { passive suffix } \\ \text { ATT } & \text { attributive form } & \text { NML } & \text { nominalizer } & \text { QT } & \text { quotative particle } \\ \text { CLS } & \text { classifier } & \text { NOM } & \text { nominative } & \text { SE } & \text { sentence extender } \\ \text { COP } & \text { copula } & \text { PST } & \text { past } & \text { TOP } & \text { topic particle } \\ \text { DAT } & \text { dative } & \text { MOD } & \text { modal expression } & \text { VOL } & \text { volitional suffix }\end{array}$


GEN genitive POL polite suffix

\begin{tabular}{|c|c|c|c|}
\hline \multicolumn{4}{|c|}{ Transcription conventions } \\
\hline [ & the point where overlapping talk starts & $=$ & 'latched' utterances \\
\hline$(0.0)$ & length of silence in tenths of a second & $?$ & rising intonation \\
\hline (.) & micro-pause less than $2 / 10$ of a second & & falling intonation \\
\hline$\because:$ & lengthened syllable & & continuing intonation \\
\hline- & cut-off & .hh & audible in-breath \\
\hline
\end{tabular}

References

Bednarek, Monika. 2006. Evaluation in media discourse: Analysis of a newspaper corpus. London: Continuum.

Biber, Douglas. 1994. An analytical framework for register studies. In Douglas Biber \& Edward Finegan (eds.), Sociolinguistic perspectives on register, 31-56. Oxford: Oxford University Press.

Biber, Douglas. 2006. University language: A corpus-based study of spoken and written registers. Amsterdam: John Benjamins.

Biber, Douglas \& Susan Conrad. 2009. Register, genre, and style. Cambridge: Cambridge University Press.

Bruthiaux, Paul. 1994. Me Tarzan, you Jane: Linguistic simplification in "personal ads" register. In Douglas Biber \& Edward Finegan (eds.), Sociolinguistic perspectives on register, 136-154. Oxford: Oxford University Press.

Bybee, Joan. 2006. From usage to grammar: The mind's response to repetition. Language 82(4). 711-733.

Bybee, Joan \& Eddington, David. 2006. A usage-based approach to Spanish verbs of 'becoming.' Language 82(2). 323-355.

Chafe, Wallace. 1994. Discourse, consciousness, and time: The flow and displacement of conscious experience in speaking and writing. Chicago: University of Chicago Press.

Cook, Haruko Minegishi. 1992. Meanings of non-referential indexes: A case study of Japanese sentence-final ne. Text 12(4). 507-539.

Du Bois, John W. 1987. The discourse basis of ergativity. Language 63. 805-855.

Ferguson, Charles A. 1983. Sports announcer talk: Syntactic aspects of register variation. Language in Society 12. 153-172.

Ferguson, Charles A. 1994. Dialect, register, and genre: Working assumptions about conventionalization. In: Douglas Biber \& Edward Finegan (eds.), Sociolinguistic perspectives on register, 15-29. Oxford: Oxford University Press.

Fillmore, Charles J. 1982. Frame semantics. In The Linguistic Society of Korea (eds.), Linguistics in the morning calm. 111-137. Seoul: Hanshin Publishing.

Fischer, Kerstin. 2013. The addressee in the recipe: How Julia Child gets to join you in the kitchen. In Cornelia Gerhardt, Maximiliane Frobenius \& Susanne Ley (eds.), Culinary linguistics: The chef's special, 103-117. Amsterdam: John Benjamins.

Fox, Barbara A., Makoto Hayashi \& Robert Jasperson. 1996. Resources and repair: A crosslinguistic study of the syntactic organization of repair. In Elinor Ochs, Emanuel A. Schegloff \& Sandra Thompson (eds.), Interaction and Grammar. 185-237. Cambridge: Cambridge University Press.

Goodwin, Charles. 1996. Transparent vision. In Elinor Ochs, Emanuel A. Schegloff \& Sandra Thompson (eds.), Interaction and Grammar. 370-404. Cambridge: Cambridge University Press.

Haig, John. 1981. Particles retention in propredicated and cleft sentences. The Journal of the Association of Teachers of Japanese 16(1). 7-29. 
Hoji, Hajime. 1990. Theories of anaphora and aspects of Japanese syntax. Unpublished Ms. http://www.gges.org/hoji/download/upload/Hoji1990.pdf

Hopper, Paul J. 1998. Emergent grammar. In Michael Tomasello (ed.), The new psychology of language: Cognitive and functional approaches to language structure, 155-175. Mahwah, NJ: Lawrence Erlbaum.

Hopper, Paul J. 2001. Grammatical constructions and their discourse origins: Prototype or family resemblance? In Martin Pütz, Susanne Niemeier \& René Dirven (eds.), Applied cognitive linguistics: Theory, acquisition and language pedagogy, 109-130. Berlin: Mouton de Gruyter.

Hopper, Paul J. 2004. The openness of grammatical constructions. Papers from the $40^{\text {th }}$ Regional Meeting of the Chicago Linguistics Society 40(2). 153-175.

Inoue, Kazuko. 1982. An interface of syntax, semantics and discourse structure. Lingua 57. 259-300.

Inoue, Yasushi. 1979. Chizu ni nai shima. Tokyo: Bunshun-bunko.

Kamio, Akio. 1979. On the notion of the speaker's territory of information. In G. Bedell, E. Kobayashi, and M. Muraki. (eds.), Explorations in linguistics: Papers in honor of Kazuko Inoue, 213-231. Tokyo: Kenkyuusha.

Kamio, Akio. 1991. Cleft sentences and the territory of information. In Carol Georgopoulos \& Roberta Ishihara (eds.), Interdisciplinary Approaches to language: Essays in honor of S. Y. Kuroda, 353-337. Dordrecht: Kluwer Academic Publishers.

MacWhinney, Brian. (2007). The TalkBank Project. In J. C. Beal, K. P. Corrigan \& H. L. Moisl (Eds.), Creating and Digitizing Language Corpora: Synchronic Databases, Vol.1.(pp. 163-180). Houndmills: Palgrave-Macmillan.

Martin, Samuel E. 1975. A reference grammar of Japanese. New Haven: Yale University Press.

Matsumoto, Yoshiko. 2015. Partnership between grammatical construction and interactional frame: The stand-alone noun-modifying construction in invocatory discourse. Constructions and Frames 7(2). 289-314.

Mori, Junko. 2014. The re-examination of so-called 'clefts': A study of multiunit turns in Japanese talk-in-interaction. In Kaori Kabata \& Tsuyoshi Ono (eds.), Usage-based approaches to Japanese grammar: Towards the understanding of human language, 193-222. Amsterdam: John Benjamins.

Nakau, Minoru. 1973. Sentential complementation in Japanese. Tokyo: Kaitakusha.

Nishihara S. 1997. Patterns of assertion and exposition in English and Japanese newspaper editorials. Japanese Discourse 2: 25-41.

Ono, Tsuyoshi \& Sandra A. Thompson. 2003. Japanese (w)atashi/ore/boku 'l': They're not just pronouns. Cognitive Linguistics 14(4). 321-347.

Pawley, Andrew \& Frances H. Syder. 1983. Natural selection in syntax: Notes on adaptive variation and change in vernacular and literary grammar. Journal of Pragmatics 7. 551579.

Prince, Ellen. 1978. A comparison of wh-clefts and it-clefts in discourse. Language 54(4). 883906.

Schegloff, Emanuel A. 1996. Turn organization: One intersection of grammar and interaction. In Elinor Ochs, Emanuel A. Schegloff \& Sandra A. Thompson (eds.), Interaction and grammar. 52-123. Cambridge \& New York: Cambridge University Press.

Schiffrin, Deborah. 1987. Discourse markers. Cambridge: Cambridge University Press.

Schiffrin, Deborah, 2001. Discourse markers: Language, meaning, and context. In: Deborah Schiffrin, Deborah Tannen \& Heidi Hamilton (eds.), The Handbook of Discourse Analysis, 54-75. Oxford: Basil Blackwell.

Sunakawa, Yuriko. 1995. Nihongo ni okeru bunretsubun no kinou to gojyun no genri [Function and the word order principle of Japanese cleft sentences]. In: Yoshio Nitta (ed.), 
Fukubun no kenkyuu [Studies of complex sentences], 353-388. Tokyo: Kuroshio Publishing.

Sunakawa, Yuriko. 2005. Bunpou to danwa no setten: nihongo no danwa ni okeru shudai tenkai kinou no kenkyuu [Interface between grammar and discourse: Study of discourse topic development function in Japanese discourse]. Tokyo: Kuroshio Publishing.

Sunakawa, Yuriko. 2007. Bunretsubun no bunpou to kinou [The grammar and discourse functions of cleft sentences]. Nihongo Bunpou [Japanese Grammar] 7(2). 20-36.

Thompson, Susan. 2003. Text-structuring metadiscourse, intonation and the signalling of organisation in academic lectures. Journal of English for Academic Purposes 2(1). 5-20.

Tomasello, Michael. 2003. Constructing a language: A usage-based theory of language acquisition. Cambridge, MA: Harvard University Press

Wittgenstein, Ludwig. 1953. Philosophical investigations (G.E.M. Anscombe, Trans.). New York: Macmillan. 